\title{
Identification of erythrocyte-binding antigens in Helicobacter pylori
}

\author{
Jinzhou Huang, ${ }^{1}$ P. W. Napoleon Keeling ${ }^{2}$ and Cyril J. Smyth ${ }^{1 *}$ \\ ${ }^{1}$ Department of Microbiology, Moyne Institute, Trinity College, Dublin, Republic of Ireland \\ ${ }^{2}$ Department of Clinical Medicine, TCD Medical School Building, St. James's Hospital, Dublin, Republic of Ireland
}

(Received 8 January 1992; revised 6 March 1992; accepted 18 March 1992)

\begin{abstract}
The surface antigens of Helicobacter pylori conferring erythrocyte-binding activity were obtained by adsorption onto formaldehyde-treated dog and goat erythrocytes from supernatant fractions of sonicated bacteria and elution using a high concentration of $\mathrm{NaCl}$. The desorbed material was analysed by SDS-PAGE and immunoblotting with anti-whole-cell serum to agar-grown bacteria which had been absorbed with broth-grown, non-haemagglutinating cells (haemagglutination-associated antiserum). Two polypeptides with molecular masses of 25 and $59 \mathrm{kDa}$ were revealed as erythrocyte-binding antigens. Strains which agglutinated both dog and goat erythrocytes possessed both these erythrocyte-binding antigens, whereas an antigenically cross-reactive 24 kDa polypeptide was present in a strain which only agglutinated goat erythrocytes. Haemagglutinin material was extracted from $\boldsymbol{H}$.pylori using n-octylglucopyranoside and purified by Sepharose chromatography and sucrose density gradient ultracentrifugation. The purified extract directly agglutinated erythrocytes in a neuraminyl-lactose-sensitive and neuraminidasesensitive manner. The $59 \mathrm{kDa}$ polypeptide was not present in the purified haemagglutinin preparation. The haemagglutination-associated antiserum reacted strongly with the $25 \mathrm{kDa}$ polypeptide band which was the most prominent polypeptide band on analysis of the purified haemagglutinin preparation by SDS-PAGE and silver staining. Thus, $\boldsymbol{H}$. pylori possesses at least two adhesins, one of which recognises a $\boldsymbol{N}$-acetylneuraminic acid ( $\alpha 2-3)$ moiety of receptors, the other being of unknown receptor specificity. Differences in the antigenicity and molecular masses of these adhesins in individual strains may underlie differences in receptor-binding specificities and haemagglutination profiles.
\end{abstract}

\section{Introduction}

In vitro haemagglutinating activity of Helicobacter pylori has been demonstrated with a variety of erythrocyte species (Huang et al., 1988; Emödy et al., 1988; Evans et al., 1988; Nakazawa et al., 1989; Robinson et al., 1990). Different haemagglutination phenotypes and patterns have been suggested (Huang et al., 1988; Emödy et al., 1988; Robinson et al., 1990). Evans et al. (1988) reported a fibrillar haemagglutinin that bound specifically to $\mathrm{N}$ acetylneuraminyl-lactose (NeuAc-lactose) and proposed that this moiety was the adhesin of $H$. pylori primarily involved in gastric mucosal colonization. Unfortunately,

\footnotetext{
* Author for correspondence. Tel. 1702 2013; fax 16799294.

Abbreviations: CHAPS, 3-[(3-cholamidopropyl)dimethylammonio]1-propanesulphonate; HA, haemagglutination; HAA, haemagglutination-associated antiserum; HSA, haemagglutinin-specific antibody; NeuAc, $N$-acetylneuraminic acid; NeuAc-lactose, $N$-acetylneuraminyl-lactose; NOG, $n$-octyl- $\beta$-D-glucopyranoside; SAM, superficial adhering material; SDOC, sodium deoxycholate.
}

a molecular analysis of this fibrillar haemagglutinin was not done.

Reports of glycolipid receptors for $H$. pylori have appeared (Lingwood et al., 1989; Slomiany et al., 1989; Saitoh et al., 1991). Lingwood et al. (1989) reported that lipid extracts of human red blood cells and of human and pig stomach tissue were specifically recognized by isolates of $\boldsymbol{H}$. pylori. On the basis of chemical analysis, they proposed that the active component was a novel glycerolipid and that it was the specific gastric epithelial receptor for $\boldsymbol{H}$. pylori adherence. The reports of Slomiany et al. (1989) and Saitoh et al. (1991) using haemagglutination (HA) inhibition tests and a solid-phase TLCimmunostaining technique, respectively, identified ganglioside $\mathrm{GM}_{3}$ as a receptor molecule for $H$. pylori.

Several in vitro models utilizing mammalian cell lines have been developed for evaluation of $H$. pylori adherence. It was reported that $H$. pylori strains adhered to HEp-2, INT-407, Y-1 adrenal, and HeLa cell lines (Neman-Simha \& Megrand, 1988; Fauchère et al., 1989; Neman-Simha et al., 1989; Evans et al., 1989). Evans et 
al. (1989) also reported that $H$. pylori adherence to Y1 mouse adrenal cells was rapid, neuraminidase-sensitive, and blocked by a sialoglycoprotein rich in NeuAclactose. However, neuraminidase sensitivity was not demonstrated in other studies using HeLa cells (Fauchère et al., 1989) and human gastric carcinoma (KATO III) cells (Dunn et al., 1991) as model systems for $H$. pylori adherence.

Despite some discrepancies, the findings from the various studies on haemagglutination caused by $H$.pylori all indicate that molecular characterization of the haemagglutinins is necessary for a better understanding of this property and the nature of the ligand-receptor interaction(s). Huang et al. (1988) described $H$. pylori strains which agglutinated human red blood cells (HA phenotype 1) and others which did not (HA phenotype 2). Accordingly, attempts were made (i) to purify haemagglutinin from $H$. pylori strain 136292, which showed HA phenotype 1 activity and relatively higher HA titres compared with the other strains tested previously; (ii) to analyse, using Western blotting, the erythrocyte-binding antigens of three strains (one HA phenotype 1 and two HA phenotype 2), which exhibit different abilities and specificities in $\mathrm{HA}$ reactions observed previously (Huang et al., 1988); and (iii) to characterize the erythrocyte-binding antigens by analysis of purified haemagglutinin.

\section{Methods}

$H$. pylori strains and growth conditions. Three $H$. pylori strains were principally used in this study, namely 136292,172460 and 184858. Strain 136292 is an HA phenotype 1 strain which is strongly haemagglutinating (human, guinea-pig, sheep, dog, goat and rat erythrocytes), whereas strain 172460 strongly agglutinates only goat erythrocytes but also weakly agglutinates rat erythrocytes. Strain 184858 only agglutinates rat erythrocytes weakly. Both the latter strains are HA phenotype 2 strains (Huang et al., 1988). Two additional HA phenotype 1 strains (185706 and 133538) and one further HA phenotype 2 strain (216983) were used in certain experiments.

H. pylori were grown on $7 \%(\mathrm{v} / \mathrm{v})$ lysed horse blood Campylobacter (LBC) agar plates (without selective supplement) in an anaerobic jar (Oxoid) using a Gas Generating Kit for campylobacters (Oxoid) at $37^{\circ} \mathrm{C}$ for $48-72 \mathrm{~h}$ (Huang et al., 1988). To grow $H$. pylori in broth medium, bacteria were inoculated into $200 \mathrm{ml}$ serum broth medium containing $2 \cdot 5 \%(\mathrm{w} / \mathrm{v})$ nutrient broth No. 2 (Oxoid), $0 \cdot 5 \%(\mathrm{w} / \mathrm{v})$ yeast extract (Oxoid) and $2 \%(\mathrm{v} / \mathrm{v})$ newborn calf serum (Gibco) in a one litre flask. The flask was placed in an anaerobic jar with a Gas Generating $\mathrm{Kit}$ for campylobacters and incubated at $37^{\circ} \mathrm{C}$ for $48 \mathrm{~h}$ with constant shaking at 150 r.p.m. (New Brunswick Orbital Incubator).

$H A$ assay. Citrated dog, goat, sheep and rat blood were obtained fresh from the BioResources Unit, Trinity College, Dublin, Republic of Ireland. Citrated ox and horse blood were obtained from Abbotstown Veterinary Institute, Dublin, Republic of Ireland. Human A and O blood were outdated samples from the local blood bank. Washing of red blood cells, preparation of bacterial suspensions and the microtitration method for haemagglutination have been detailed previously (Huang $e t$ al., 1988).

$H A$ inhibition test. The following solutions were prepared in PBS $(0 \cdot 145 \mathrm{M}-\mathrm{NaCl}, 10 \mathrm{mM}$-sodium phosphate buffer, $\mathrm{pH} 7 \cdot 2)$ for use in HA inhibition tests: NeuAc-lactose from bovine colostrum [mixture of NeuAc $(\alpha 2-3) \mathrm{Gal}(\beta 1-4) \mathrm{Glc}, 85 \%$ and $\cdot \operatorname{NeuAc}(\alpha 2-6) \mathrm{Gal}(\beta 1-4) \mathrm{Glc}$, $15 \%$ ] and NeuAc-lactose from human milk [mixture of NeuAc $(\alpha 2-$ 3) Gal $(\beta 1-4) \mathrm{Glc}, \quad 15 \%$ and $\operatorname{NeuAc}(\alpha 2-6) \mathrm{Gal}(\beta 1-4) \mathrm{Glc}, \quad 85 \%]$ $\left(2 \mathrm{mg} \mathrm{ml}^{-1}\right) ; N$-acetylneuraminic acid (NeuAc) from egg yolk and synthetic NeuAc $\left(2 \mathrm{mg} \mathrm{ml}^{-1}\right)$. These sugars were obtained from Sigma.

Each well in the inhibition assays contained $25 \mu \mathrm{l}$ of a twofold dilution of bacterial suspension or haemagglutinin sample, $25 \mu \mathrm{l}$ test inhibitor, and $25 \mu$ l erythrocyte suspension (both 3 and $1.5 \%$ packed cell volume suspensions were used). Controls contained $25 \mu 1$ PBS instead of test inhibitor. Titrations were incubated and read as for the microtitration HA assay (Huang et al., 1988). Tests were performed in parallel with dog, goat, horse, ox, sheep and human A erythrocyte suspensions with each of the $H$. pylori strains tested.

Neuraminidase treatment of erythrocytes. Erythrocytes were sedimented, washed twice and resuspended to $3 \%(\mathrm{v} / \mathrm{v})$ packed cell volume in either PBS (pH 7.2) or acetate buffered saline ( $0.145 \mathrm{M}-\mathrm{NaCl}, 10 \mathrm{~mm}$ sodium acetate/acetic acid buffer, pH 5.2). Dog, goat, horse, ox, sheep and human A erythrocyte suspensions ( $3 \%$ packed cell volume in buffered saline) were treated with Clostridium perfringens type $\mathrm{X}$ neuraminidase (Sigma) at $0 \cdot 1 \mathrm{U} \mathrm{ml}^{-1}$ for $1 \mathrm{~h}$ at $37^{\circ} \mathrm{C}$. Neuraminidases from Vibrio cholerae (Sigma) and from Arthrobacter ureafaciens (Boehringer Mannheim) were also used $\left(0 \cdot 1 \mathrm{U} \mathrm{ml}^{-1}\right.$ at $37^{\circ} \mathrm{C}$ for $1 \mathrm{~h}$ ) in the treatment tests. Two batches of each type of neuraminidase were tested. The neuraminidase-treated erythtocytes were sedimented, washed twice with PBS and resuspended to the original volume in PBS. Haemagglutinin samples as well as $\boldsymbol{H}$. pylori bacteria were tested with the treated and control suspensions of erythrocytes. Lectins from Arachis hypogaea [Sigma; $\beta$-D-Gal(1-3)-D-GalNAc-specific] and Limulus polyphemus (Sigma; NeuAc-specific) were used to check the efficiency of the neuraminidase treatment. Peanut agglutinin does not agglutinate normal human erythrocytes, but strongly agglutinates neuraminidase-treated erythrocytes. Neuraminidase-treated human erythrocytes are not agglutinated by Limulus polyphemus agglutinin.

Protease and heat treatments of purified haemagglutinin. These were performed as previously described for $H$. pylori (Huang et al., 1988).

Production of antisera to H. pylori whole cells. H. pylori strains 136292 , 172460 and 184858 were used individually. Bacteria lawned onto LBC agar plates and grown as above $\left(37^{\circ} \mathrm{C}, 48 \mathrm{~h}\right)$ were harvested and washed twice with PBS (pH 7.2), once with PBS containing $0.5 \%(\mathrm{w} / \mathrm{v})$ formaldehyde, and finally resuspended in PBS containing $0.5 \%$ formaldehyde [ $1 \mathrm{~g}$ (wet $\mathrm{wt}$ ) bacteria per $100 \mathrm{ml}$ suspension]. Adult New Zealand white rabbits were immunized intravenously at 7-d intervals for 6 weeks with a constant dose of $0.5 \mathrm{ml}$ formaldehyde-treated bacterial suspension for each injection. The rabbits were bled $12 \mathrm{~d}$ after the last injection. The sera were separated and stored at $-20^{\circ} \mathrm{C}$.

Preparation of $H A$-associated antiserum (HAA). Antiserum raised against agar-grown bacteria of strain 136292 was absorbed with brothgrown bacteria of the same strain which had been serially passaged in the broth medium until harvested bacteria were non-haemagglutinating as tested by the microtitration method. Absorption was performed by incubating the antiserum with washed broth-grown bacterial cells [about $2 \mathrm{~g}$ (wet wt) per $100 \mathrm{ml}$ antiserum] at $4{ }^{\circ} \mathrm{C}$ for $6-12 \mathrm{~h}$ followed by removal of the bacteria by centrifugation at $8000 \mathrm{~g}$ for $10 \mathrm{~min}$ at $4^{\circ} \mathrm{C}$. This procedure was repeated three times.

Preparation of haemagglutinin-specific antibody (HSA). Of the haemagglutinin sample (see Results), $3 \mathrm{ml}$ (approximately $1 \mathrm{mg}$ 


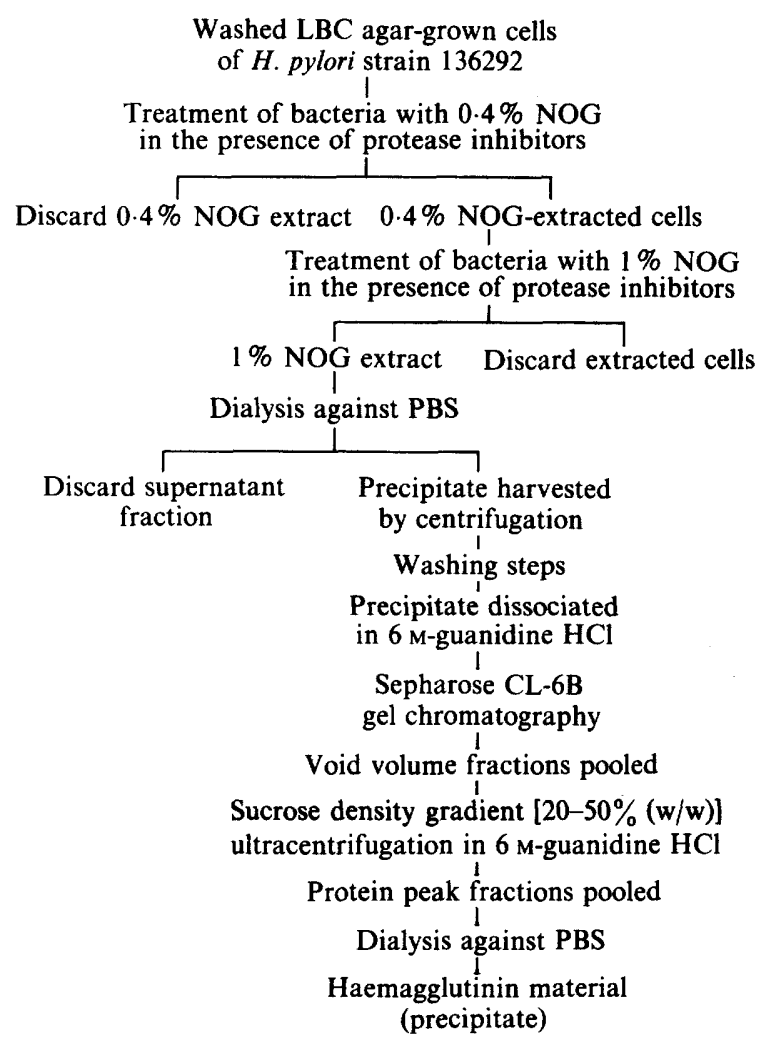

Fig. 1. Flow scheme of purification of $\boldsymbol{H}$. pylori haemagglutinin.

protein) was centrifuged (Eppendorf centrifuge, $7000 \mathrm{~g}, 5 \mathrm{~min}$ ) and the pellet resuspended in $1 \mathrm{ml}$ PBS containing $1.5 \%(w / v)$ bovine serum albumin (BSA, Sigma) and incubated for $15 \mathrm{~min}$ at $18-20^{\circ} \mathrm{C}$. Antiserum raised against whole cells of agar-grown $H$. pylori strain $136292(500 \mu \mathrm{l})$ was added to the suspension. After incubation for $30 \mathrm{~min}$ at $18-20^{\circ} \mathrm{C}$, the mixture was centrifuged to sediment the complex of antibody-haemagglutinin material. The pellet was washed three times with PBS, and then resuspended in $1 \mathrm{ml}$ glycine $\mathrm{HCl}$ buffer $(0.2 \mathrm{M}, \mathrm{pH} 2.2)$ for $10 \mathrm{~min}$. After centrifugation $(7000 \mathrm{~g}, 5 \mathrm{~min})$ the supernatant fraction containing desorbed antibodies was neutralized with $1 \mathrm{M}-\mathrm{NaOH}$. This constituted the HSA.

Tests on the effects of detergents on HA activity. Graded quantities of washed cells of $H$. pylori strain 136292 were each suspended in $1 \mathrm{ml}$ PBS containing various concentrations (from 0.2 to $1 \%, \mathrm{w} / \mathrm{v}$, of detergents and $2 \mathrm{mM}$-PMSF) and $2 \mathrm{mM}$-benzamidine to yield various final bacterial cell concentrations $(2,4$ and $6 \%$, wet $w / v)$. The bacterial suspensions were incubated for $15 \mathrm{~min}$ at $18-20^{\circ} \mathrm{C}$. The bacteria were recovered by centrifugation $(6000 \mathrm{~g}, 10 \mathrm{~min})$, washed once with PBS, resuspended in PBS (about $5 \times 10^{10}$ cells ml-1) and tested for their HA titres against dog erythrocytes using the microtitration method. The following detergents were tested: $n$-octyl- $\beta$-D-glucopyranoside (NOG), 3-[(3-cholamidopropyl)dimethyl-ammonio]-1-propanesulphonate (CHAPS), and sodium deoxycholate (SDOC) (all from Sigma).

Preparation of haemagglutinin sample. An overview of the final standard purification scheme is presented in Fig. 1. Washed cells of $\boldsymbol{H}$. pylori strain 136292 (about $0.5 \mathrm{~g}$ wet wt) from 30 LBC-agar plates were suspended in $12 \mathrm{ml}$ PBS containing $0.4 \%$ NOG, 2 mM-PMSF and 2 mM-benzamidine for $15 \mathrm{~min}$ at $18-20^{\circ} \mathrm{C}$. The bacteria were recovered by centrifugation $(6000 \mathrm{~g}, 10 \mathrm{~min})$, the supernatant fraction discarded and the bacteria resuspended in $12 \mathrm{ml}$ PBS with protease inhibitors and $1 \%(w / v)$ NOG, for a further $15 \mathrm{~min}$. After centrifugation the supernatant fraction was dialysed against PBS for $24 \mathrm{~h}$ at $4{ }^{\circ} \mathrm{C}$ with three changes of PBS. The precipitate which formed after dialysis was harvested by centrifugation $(8000 \mathrm{~g}, 10 \mathrm{~min})$ and washed once in PBS, once in PBS containing $1 \%$ CHAPS, twice more in PBS and then dispersed or dissociated in $2 \mathrm{ml}$ PBS containing $6 \mathrm{M}$-guanidine $\mathrm{HCl}$ (Sigma). After centrifugation at $10000 \mathrm{~g}$ for $15 \mathrm{~min}$ the supernatant fraction was applied onto a Sepharose CL-6B gel bed $(1.5 \times 40 \mathrm{~cm})$ using PBS containing $6 \mathrm{M}$-guanidine $\mathrm{HCl}$ as elution buffer. Fractions containing the void-volume material were pooled (about $5 \mathrm{ml}$ in total). Of the pooled sample, $2.5 \mathrm{ml}$ aliquots were directly applied onto linear sucrose density gradients $[12 \mathrm{ml}, 20-50 \%(\mathrm{w} / \mathrm{w})$ sucrose in distilled water containing $6 \mathrm{M}$-guanidine $\mathrm{HCl}$ ]. After ultracentrifugation $\left(100000 \mathrm{~g}, 20 \mathrm{~h}, 18^{\circ} \mathrm{C}\right)$ the gradients were fractionated and fractions (about $1.5 \mathrm{ml}$ each) monitored for $A_{280}$. Selected fractions were dialysed against PBS and tested for their haemagglutinating activities.

Erythrocyte-binding tests. Citrated fresh dog and goat erythrocytes were washed three times with PBS and prepared as $5 \%(\mathrm{v} / \mathrm{v})$ suspensions of packed cell volumes in PBS. Formaldehyde $(40 \%, \mathrm{w} / \mathrm{v})$ was added dropwise, with stirring, to the erythrocyte suspensions to a final concentration of $10 \%(w / v)$. Gentle stirring continued over $24 \mathrm{~h}$ at $4{ }^{\circ} \mathrm{C}$. The formaldehyde-treated cells were sedimented $(3500 \mathrm{~g}, 5 \mathrm{~min})$ and washed six times with $0.15 \mathrm{M}-\mathrm{NaCl}$ and finally prepared as $2.5 \%$ $(\mathrm{v} / \mathrm{v})$ suspensions of packed cell volume in PBS.

Agar-grown $H$. pylori cells (strains 136292, 172460 and 184858 separately) were washed three times with PBS and resuspended as $2 \%$ $(\mathrm{v} / \mathrm{v})$ packed cell volume suspensions in PBS. The tube containing each bacterial suspension was placed in a beaker with iced salt water and sonicated (MSE ultrasonicator) at full power $(10 \times 10 \mathrm{~s}$ bursts with $20 \mathrm{~s}$ pauses in between). Debris was removed by centrifugation $(10000 \mathrm{~g}$, $15 \mathrm{~min}, 4^{\circ} \mathrm{C}$ ).

Each supernatant fraction was assayed in an erythrocyte-binding test as follows. To $200 \mu \mathrm{l}$ formaldehyde-treated erythrocyte suspension in a Eppendorf tube $200 \mu \mathrm{l} 5 \%$ (w/v) BSA in PBS was added and the mixture incubated at $18-22{ }^{\circ} \mathrm{C}$ for $15 \mathrm{~min}$. To this $600 \mu \mathrm{l}$ supernatant fraction of sonicated bacteria was added and the mixture incubated for a further $30 \mathrm{~min}$. The Eppendorf tube was briefly centrifuged (about $7000 \mathrm{~g}, 10 \mathrm{~s}$ ) to pellet the erythrocytes. The pellet was washed three times with PBS. After the last washing the pellet was suspended in $80 \mu \mathrm{l}$ $1.5 \mathrm{M}-\mathrm{NaCl}$ for $15 \mathrm{~min}$ at room temperature. After centrifugation (7000 $g, 10 \mathrm{~s})$ the supernatant fraction was removed and dialysed against distilled water overnight at $4{ }^{\circ} \mathrm{C}$. Of each dialysed sample $40 \mu \mathrm{l}$ was analysed by SDS-PAGE and Western blotting.

$S D S-P A G E$ and gel staining. SDS-PAGE was performed essentially as described by Laemmli (1970) using $12 \%(w / v)$ acrylamide separating gels. Bacteria ( $200 \mu \mathrm{g}$ protein) were boiled in $100 \mu \mathrm{l}$ sample buffer for $5 \mathrm{~min}$ and the lysate centrifuged $(7000 \mathrm{~g}, 2 \mathrm{~min})$ to obtain a supernatant fraction. For visualizing protein profiles, gels were stained with Coomassie brilliant blue $\mathbf{R}-250$. In some experiments gels were silverstained by the method of Wray et al. (1981). Carbohydrate was detected by the highly sensitive periodic acid-silver stain (Dubray \& Bezard, 1982).

Immunoblotting technique. The Western blotting technique of Burnette (1982) was used for immunoblotting. After electrophoresis, the polypeptides separated by SDS-PAGE were transferred electrophoretically to a nitrocellulose filter (BA85, pore size $0.45 \mu \mathrm{m}$, Schleicher \& Schuell). This was then soaked in Tris/HCl-buffered saline (TBS; $10 \mathrm{mM}-\mathrm{Tris} / \mathrm{HCl}, 0.15 \mathrm{M}-\mathrm{NaCl}, \mathrm{pH} 7.5$ ) containing $2 \%$ BSA for $60 \mathrm{~min}$ at $18-20^{\circ} \mathrm{C}$ and then transferred for $90 \mathrm{~min}$ to antiserum, which had been diluted $1: 100$ in TBS containing $1 \%$ BSA. After being washed with TBS the filter was incubated with a 1:1000 dilution of horseradish-peroxidase-conjugated Protein A (Sigma) in TBS containing $1 \%(\mathrm{w} / \mathrm{v})$ BSA for $60 \mathrm{~min}$. After being washed again, 
Table 1. HA-inhibition by NeuAc-lactose from bovine colostrum and from human milk when tested with bacterial cells of $H$. pylori strain 136292 and erythrocytes of six species

Results shown are representative of duplicate experiments with strain 136292; similar patterns of HA inhibition were also obtained in duplicate experiments with strains $185706,133538,216983$, and 172460 (strain 172460 was tested only with goat red blood cells), although absolute titres differed from those below; final concentrations of NeuAc-lactose and erythrocytes in wells were $667 \mu \mathrm{g} \mathrm{ml}^{-1}$ and $0.5 \%(\mathrm{v} / \mathrm{v})$, respectively.

\begin{tabular}{|c|c|c|c|c|c|c|}
\hline \multirow{2}{*}{$\begin{array}{l}\text { Haemagglutination } \\
\text { conditions }\end{array}$} & \multicolumn{6}{|c|}{ HA titres for indicated erythrocyte species } \\
\hline & Human A & Sheep & Dog & Goat & Bovine & Horse \\
\hline $\begin{array}{l}H . \text { pylori cells }+ \text { PBS } \\
H . \text { pylori cells }+ \text { bovine }\end{array}$ & 32 & 32 & 128 & 64 & 32 & 32 \\
\hline $\begin{array}{l}\text { NeuAc-lactose in PBS } \\
\text { H. pylori cells }+ \text { human }\end{array}$ & 4 & 4 & $32-64$ & 64 & $16-32$ & $16-32$ \\
\hline NeuAc-lactose in PBS & 8 & 32 & 128 & 64 & 32 & 32 \\
\hline
\end{tabular}

the blots were developed in TBS containing $0.06 \%$ (w/v) 4-chloro-1naphthol and $0.01 \%(\mathrm{v} / \mathrm{v}) \mathrm{H}_{2} \mathrm{O}_{2}$. The reaction was stopped by washing in distilled water.

Protein determination. Protein concentration was determined by the method of Markwell et al. (1978). BSA was used as standard. This method is a modification of the Lowry procedure to simplify protein determination in membrane and lipoprotein samples.

Electron microscopy. (a) Negative staining method. Samples to be examined were placed on copper grids bearing a carbon-coated formvar film. The grids were drained with filter paper after $2 \mathrm{~min}$, negatively stained with $1 \%(\mathrm{w} / \mathrm{v})$ silicotungstate for $1 \mathrm{~min}$, and finally air-dried. Grids were examined with a Hitachi H-700 transmission electron microscope at $100 \mathrm{kV}$.

(b) Thin section method. Bacterial suspensions or haemagglutinin samples were mixed with equal volumes of $3 \%(v / v)$ fresh erythrocyte suspensions in wells of a white tile and rocked. After haemagglutination the supernatant fractions were removed with a Pasteur pipette and the agglutinated erythrocytes set in $2 \%(w / v)$ SeaPlaque low-gellingtemperature $\left(28-30^{\circ} \mathrm{C}\right)$ agarose (FMC BioProducts). Small (about $1 \mathrm{~mm}^{3}$ ) blocks of the gelled agarose were cut and fixed for $2 \mathrm{~h}$ at room temperature with $3 \%(\mathrm{v} / \mathrm{v})$ glutaraldehyde in $0.1 \mathrm{M}$-sodium cacodylate buffer ( $\mathrm{pH} 7 \cdot 2$ ). After being washed six times with $0.05 \mathrm{M}$-potassium phosphate buffer ( $\mathrm{pH} 7 \cdot 2$ ), the blocks were further fixed with $2 \%(\mathrm{w} / \mathrm{v})$ $\mathrm{OsO}_{4}$ in $0.1 \mathrm{M}$-sodium cacodylate buffer $(\mathrm{pH} \mathrm{7.2)}$ for $2 \mathrm{~h}$ at room temperature $\left(18-20^{\circ} \mathrm{C}\right)$. After dehydration with a graded series of ethanol solutions and treatment with transitional fluid (propylene oxide), the specimens were embedded in resin (Emix resin kit). Thin sections $(70 \mathrm{~nm})$ were cut with a glass knife (Ultramicrotome) and stained with uranyl acetate and lead citrate.

\section{Results}

\section{$H A$ inhibition}

In a broad survey (Huang et al., 1988) NeuAc-lactose (at a final concentration of $1.67 \mathrm{mg} \mathrm{ml}^{-1}$ ) was reported not to inhibit haemagglutination by bacterial cells of each of three HA phenotype $1 \mathrm{H}$. pylori strains including strain 136292. In addition, NeuAc and galactose as a mixture of monosaccharides did not inhibit. Shortly after publica- tion of these findings, the report of Evans et al. (1988) appeared describing a NeuAc-lactose-binding fibrillar haemagglutinin on $\boldsymbol{H}$. pylori. They noted that NeuAclactose from bovine colostrum [85\% $\mathrm{NeuAc}(\alpha 2-3) \mathrm{Gal}]$ but not NeuAc-lactose of human origin [85\% NeuAc $(\alpha 2-$ 6)Gal] inhibited haemagglutination of bovine and human erythrocytes. Although not stated in Huang et al. (1988), the NeuAc-lactose used in those studies was of human origin. Accordingly, in light of the findings of Evans et al. (1988), it became necessary for us to reassess our original observations on NeuAc-lactose as a potential inhibitor of $\boldsymbol{H}$. pylori haemagglutination.

NeuAc-lactose from bovine colostrum and from human milk, NeuAc from egg yolk and synthetic NeuAc were tested in the microtitration assay for their abilities to inhibit haemagglutination. Replicate bacterial titrations were performed. Also, in order to improve the sensitivity of HA inhibition, $1.5 \%$ ( $/ \mathrm{v}$ packed cells) erythrocyte suspensions were used instead of the standard $3 \%$ erythrocyte suspensions that had previously been used (Huang et al., 1988).

In no experiment with any of the six test erythrocyte species (human A, sheep, dog, goat, bovine and horse) was inhibition by egg yolk NeuAc or synthetic NeuAc observed. NeuAc-lactose, from both bovine and human milk, caused some inhibition when strain 136292 was tested using the microtitration system (Table 1). Essentially identical findings were obtained with another four strains tested including two HA phenotype 2 strains, viz. 172460 and 216983 . The ability of NeuAc-lactose to inhibit haemagglutination varied with the erythrocyte species rather than the bacterial strain tested. With NeuAc-lactose from bovine colostrum, no inhibition was observed with goat red blood cells, slight inhibition (i.e. drop in end-point reading from $3+$ or $2+$ to $1+$ or \pm ) with bovine and horse erythrocytes, weak inhibition (two-fourfold reduction in HA titre) with dog red blood 
cells, and marked inhibition with human and sheep erythrocytes. For NeuAc-lactose from human milk, however, a fourfold inhibition effect was found only with human red blood cells. However, even when using almost ten times the minimum inhibitory concentration of bovine NeuAc-lactose as reported by Evans et al. (1988), complete inhibition of $H$. pylori haemagglutination was not achieved.

\section{Treatment of erythrocytes with neuraminidase}

Neuraminidase (ex Clostridium perfringens) treatment of $\mathrm{dog}$, goat, horse, bovine, sheep and human $\mathrm{A}$ erythrocytes at a concentration of $0.1 \mathrm{U} \mathrm{ml}^{-1}$ at $37^{\circ} \mathrm{C}$ for $1 \mathrm{~h} \mathrm{did}$ not affect the HA titres of the three HA phenotype 1 strains (133538, 136292 and 185706) and two HA phenotype 2 strains (172460 and 216983) of $H$. pylori. Lectin agglutinability (Arachis hypogaea agglutinin and Limulus polyphemus agglutinin) was used to control the efficiency of the neuraminidase treatment of the erythrocytes. Neuraminidase treatment of erythrocytes rendered them inagglutinable by horseshoe lectin (NeuAcspecific) but agglutinable by peanut agglutinin indicating removal of the NeuAc. In addition, erythrocytes treated with neuraminidases from Vibrio cholerae (Sigma) and from Arthrobacter ureafaciens (Boehringer Mannheim) $\left(0.1 \mathrm{U} \mathrm{ml}^{-1}\right.$ at $37^{\circ} \mathrm{C}$ for $\left.1 \mathrm{~h}\right)$ were also agglutinated to the same titres as control erythrocytes.

The failure of neuraminidase treatment to inhibit haemagglutination, the variation in $\mathrm{HA}$ inhibition effects observed with bovine NeuAc-lactose with different erythrocyte species and the different HA phenotypes already observed (Huang et al., 1988) strongly suggested that multiple haemagglutinins might be present on $H$. pylori.

Whole bacterial cell protein profiles of $H$. pylori strains examined by SDS-PAGE and by Western blotting using anti-whole-cell sera

$H$. pylori strains grown on $\mathrm{LBC}$ agar plates showed very similar protein profiles by SDS-PAGE (Fig. $2 a$ ). The molecular masses of the major polypeptide bands in the gels appeared to be $68,63,59,54-55$ (doublet), 45, 30 and $22 \mathrm{kDa}$. There were, however, some differences between strains in minor bands seen. To test the reactivities of anti-whole-cell sera, Western blotting of whole-cell samples of strains 136292,184858 , and 172460 was performed (Fig. 2b,c,d). The 63, 45 and $22 \mathrm{kDa}$ polypeptide bands, reacted weakly or not at all with homologous antiserum, whereas some minor bands, e.g. the $25 \mathrm{kDa}$ polypeptide band, reacted strongly with antiwhole-cell sera. The 59 and $25 \mathrm{kDa}$ polypeptide bands of all three strains displayed antigenic cross-reactivities between strains. With respect to the $25 \mathrm{kDa}$ polypeptide, strain 172460 showed differences from the other two strains not only in antigenic reactivity, but also in its molecular mass value which was slightly smaller $(24 \mathrm{kDa})$. In the case of the 17 and $16 \mathrm{kDa}$ polypeptides, the three antisera manifested totally different reactivities. The 17 and $16 \mathrm{kDa}$ antigens of the three strains were immunostained only by the anti-strain 184858 serum and by the anti-strain 136292 serum, respectively.

\section{Identification of the erythrocyte-binding antigens of $H$. pylori}

Formaldehyde-treated dog and goat erythrocytes yielded the same HA titres as freshly washed untreated erythrocytes did when tested with three strains of $H$. pylori $(136292,172460$ and 184858), suggesting that the receptors recognized by the haemagglutinin(s) of $H$. pylori had not been affected by the formaldehyde treatment. After incubation of the formaldehyde-treated erythrocytes with the supernatant fractions from sonicated bacterial cells of strains 136292,184858 and 172460 followed by elution of absorbed material with a high concentration of $\mathrm{NaCl}$, the desorbed dialysed fractions were analysed by SDS-PAGE, electrotransfer, and immunoblotting with a pooled anti-whole-cell antiserum (a mixture of equal volumes of the anti-whole-cell sera against these three strains).

Two antigenic polypeptides with molecular masses of 25 and $59 \mathrm{kDa}$, respectively, were detected in both lanes on to which had been applied, respectively, material desorbed from formaldehyde-treated dog and goat erythrocytes incubated with supernatant fractions of sonicated cells of strain 136292 (Fig. 3, lanes 4 and 5). For strain 172460 (Fig. 3, lanes 6 and 7) only material eluted from goat erythrocytes showed a well immunostained band, which had a molecular mass slightly lower $(24 \mathrm{kDa})$ than that of the $25 \mathrm{kDa}$ antigen of strain 136292. A $59 \mathrm{kDa}$ band was also visible but faint. However, corresponding $25 \mathrm{kDa}$ and $59 \mathrm{kDa}$ bands in strain 184858 were not detected (Fig. 3, lanes 2 and 3). It is improbable that the failure to detect antigens corresponding to these polypeptides was due to failure to elute them from the erythrocytes but rather that they did not bind to the erythrocytes, as strain 184858 does not agglutinate either of these erythrocyte species.

\section{Extraction and purification of haemagglutinin-containing material}

Different concentrations of NOG were tested for their effects on the haemagglutinating activity of strain 
(a)

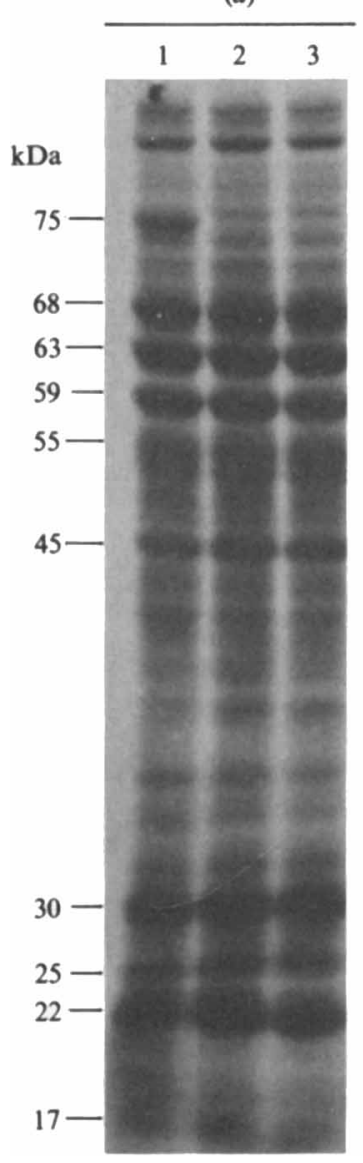

(b)

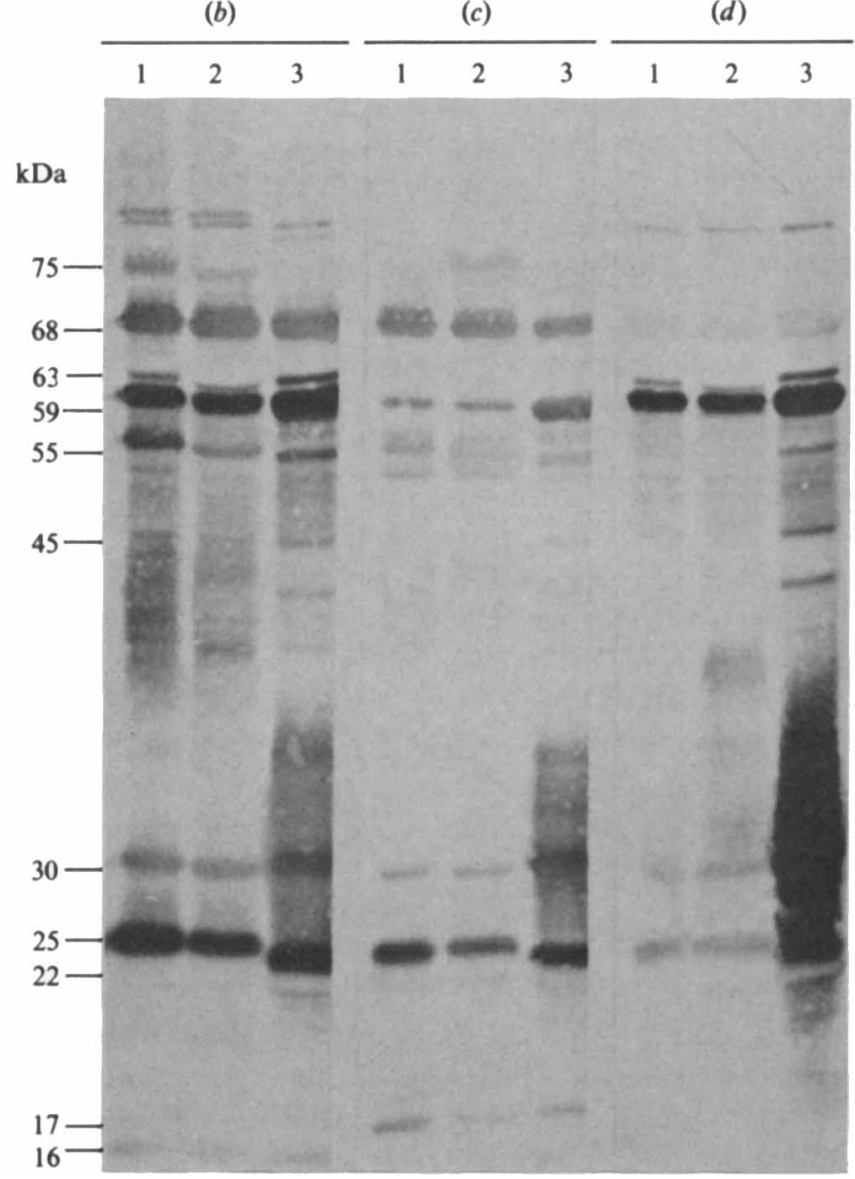

Fig. 2. SDS-PAGE analysis of whole-cell protein profiles of three $H$. pylori strains and antigenic analysis by Western immunoblotting. (a) Agar-grown bacteria, stained with Coomassie brilliant blue, $50 \mu \mathrm{g}$ protein per lane. Lanes: $1-3$, strains 136292,184858 and 172460 , respectively. $(b, c, d)$ Electrotransferred protein profiles of the three strains reacted with anti-whole-cell sera ( $(1: 100$ dilutions) against strains 136292,184858 and 172460 , respectively; $25 \mu \mathrm{g}$ protein per lane. Lanes as for $(a)$.

136292. A concentration of $0.4 \%$ (w/v) NOG was found to have little effect on the HA titres, whereas $0.8 \%$ NOG almost completely removed the haemagglutinating ability of the bacteria. The other detergents tested, namely CHAPS and SDOC, had no significant effects even at final concentrations of $1 \%(\mathrm{w} / \mathrm{v})$. Attempts to extract active haemagglutinin from strain 136292 directly with $1 \%(\mathrm{w} / \mathrm{v})$ NOG failed. Pretreatment of the bacteria with $0.4 \%$ NOG, followed by centrifugation and extraction with $1 \%$ NOG yielded material which precipitated on dialysis. The harvested precipitate agglutinated erythrocytes. Interestingly, haemagglutinating extracts were also obtained by using $1 \%(\mathrm{w} / \mathrm{v})$ CHAPS or $1 \%(\mathrm{w} / \mathrm{v})$ SDOC in place of $0.4 \%$ NOG for the initial extraction. The haemagglutinating precipitate could be dispersed or dissociated in $1.0 \%$ NOG or in guanidine $\mathrm{HCl}$ (from 5 to $8.6 \mathrm{M}$ ) but not in $1 \%$ CHAPS. The 'solubilized' material in either NOG or guanidine $\mathrm{HCl}$ could be recovered by dialysis against PBS. The resulting precipitate showed no significant loss of haemagglutinating activity.

Based on these findings a scheme was developed to purify the haemagglutinin as described in Methods (Fig. 1). After gel chromatography of the haemagglutinin material 'solubilized' in $6 \mathrm{M}$-guanidine $\mathrm{HCl}$ on a Sepharose CL-6B column in the presence of $6 \mathrm{M}$ guanidine $\mathrm{HCl}$, more than $95 \%$ of the applied material was eluted in the void volume of the column as detected by measuring $A_{280}$, indicating that the extract was not truly solubilized by the guanidine $\mathrm{HCl}$. Following sucrose density gradient ultracentrifugation of the pooled void-volume fractions from Sepharose chromatography in the presence of $6 \mathrm{M}$-guanidine $\mathrm{HCl}$, a sharp greyish-white band was present in the gradient. The fractions containing this material had the maximum absorbances at $280 \mathrm{~nm}$. After dialysis the peak fraction (about $2 \mathrm{ml}$ ) had a protein content of about $0.3 \mathrm{mg} \mathrm{ml}^{-1}$. 


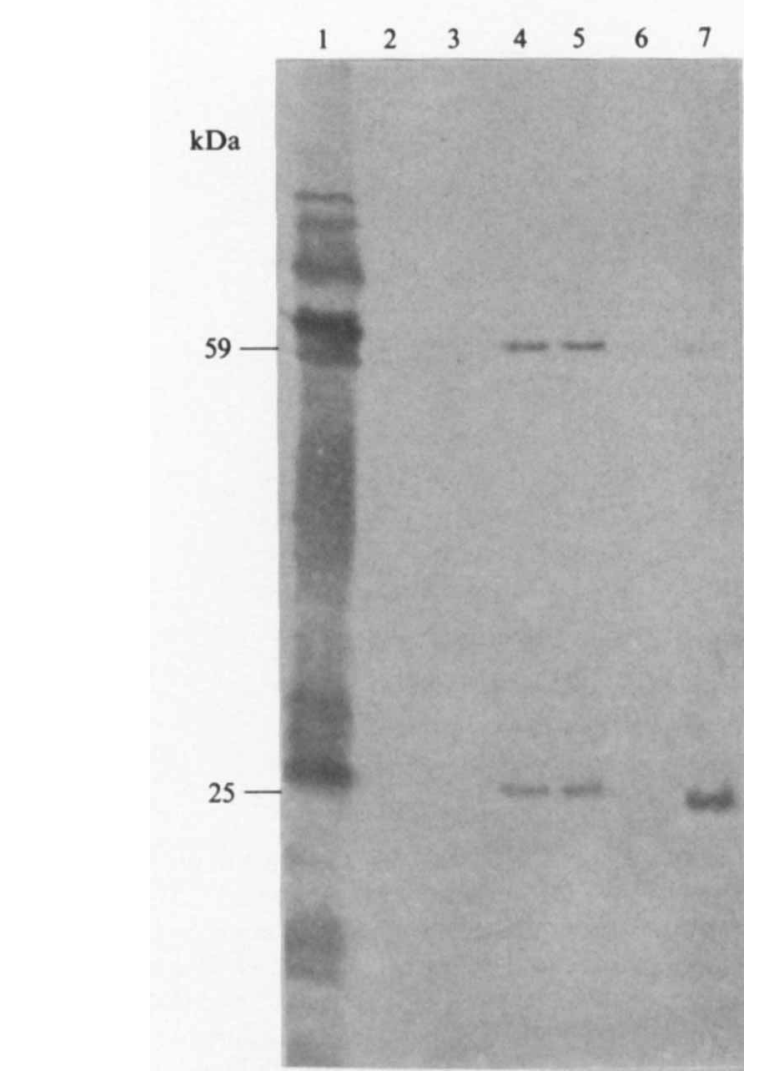

Fig. 3. Erythrocyte-binding antigens of $H$. pylori identified by immunoblotting. Lanes: 1, whole-cell lysate of strain 136292; 2 and 3, eluates from formaldehyde-treated dog (lane 2) and goat (lane 3) erythrocytes pre-incubated with the supernatant fraction of a sonicated bacterial suspension of strain $184858 ; 4$ and 5 , eluates from formaldehyde-treated dog (lane 4) and goat (lane 5) erythrocytes preincubated with the supernatant fraction of a sonicated bacterial suspension of strain 136292; 6 and 7, eluates from formaldehydetreated dog (lane 6) and goat (lane 7) erythrocytes pre-incubated with the supernatant fraction of a sonicated bacterial suspension of strain 172460. Pooled serum comprising equal volumes of anti-whole-cell sera to the three corresponding strains was used as the first antibody.

Analysis of the purified haemagglutinin of $H$. pylori strain 136292

By serial twofold dilution assay, the haemagglutinin sample from strain 136292 purified by NOG extraction, Sepharose CL-6B column chromatography and density gradient ultracentrifugation, agglutinated dog, goat and human erythrocytes at a minimum concentration of about 10,75 and $75 \mu \mathrm{g} \mathrm{ml}^{-1}$, respectively, for a $1.5 \%$ erythrocyte suspension (final concentration).

The previous findings (Huang et al., 1988) that heat and protease treatments of bacteria resulted in the abolition of the ability of $\mathrm{H}$. pylori to agglutinate erythrocytes were reproduced with the haemagglutinin sample. After heating at $56^{\circ} \mathrm{C}$ for 5 min or treatment with $\alpha$-chymotrypsin $\left(100 \mu \mathrm{g} \mathrm{ml}^{-1}\right.$, final concentration $)$, $\beta$-chymotrypsin $\left(200 \mu \mathrm{g} \mathrm{ml}^{-1}\right)$, trypsin $\left(200 \mu \mathrm{g} \mathrm{ml}^{-1}\right)$ or pronase $\left(100 \mu \mathrm{g} \mathrm{ml}^{-1}\right)$ at $37^{\circ} \mathrm{C}$ for $20 \mathrm{~min}$ and then washing with PBS, the haemagglutinin sample $(150 \mu \mathrm{g}$ protein $\mathrm{ml}^{-1}$ ) showed no haemagglutinating activity against dog, goat, or human erythrocytes.

However, a difference between the behaviour of bacterial cells of strain 136292 and the haemagglutinin sample derived from this strain was found in relation to the use of neuraminidase-treated erythrocytes in the HA test. Whereas neuraminidase treatment of erythrocytes did not affect the HA titres with bacterial cells, the same treatment of dog, goat and human red blood cells caused abolition of haemagglutination by the purified haemagglutinin sample.

Also, in contrast to the previous findings that NeuAclactose from bovine colostrum was inhibitory to different degrees on haemagglutination of erythrocytes by $H$. pylori strain 136292, when similar HA inhibition assays (NeuAc-lactose, final concentration $667 \mu \mathrm{g} \mathrm{ml}^{-1}$; erythrocytes, final concentration $1 \%, v / v)$ were carried out with the purified haemagglutinin sample (final concentration $100 \mu \mathrm{g} \mathrm{ml}^{-1}$ ), complete inhibition occurred with all the test erythrocyte species (human A, sheep, dog, goat, bovine and horse).

In Coomassie-brilliant-blue-stained SDS-PAGE gels the haemagglutinin sample (Fig. $4 a$, lane 2) revealed three major polypeptides on the basis of staining intensity with molecular masses of 75, 68 and 54-55 (doublet) kDa, respectively. Less intensely stained bands had molecular masses of 30, 25 and 16 (doublet) $\mathrm{kDa}$. In contrast, the $25 \mathrm{kDa}$ polypeptide band was the most prominent in silver-stained SDS-PAGE gels (Fig. $4 b$, lane 2).

Whole cells of strain 136292 and the haemagglutinin sample were solubilized in the sample buffer and run as paired samples in triplicate, immunoblotted and probed with antisera with different specificities. Antiserum to whole cells of strain 136292 reacted strongly with the $25 \mathrm{kDa}$ polypeptide band and less intensely with the 68 , 54 and $16 \mathrm{kDa}$ polypeptide bands of the haemagglutinin sample (Fig. $4 c$, lane 2). The HAA, prepared from the antiserum to agar-grown whole cells of strain 136292 by absorption with broth-grown, non-haemagglutinating bacteria, reacted with the $25 \mathrm{kDa}$ polypeptide band and less intensely with the $16 \mathrm{kDa}$ polypeptide band in both the whole cell and haemagglutinin samples (Fig. $4 d$, lanes 1 and 2). In contrast, a $59 \mathrm{kDa}$ polypeptide band of the whole cell sample, which was absent in the purified haemagglutinin sample, reacted strongly with this absorbed antiserum (Fig. $4 d$, lane 1). With this exception, a similarity was found in the reactivities of the HAA and the HSA against the haemagglutinin material. However, the $25 \mathrm{kDa}$ polypeptide bands of both the 


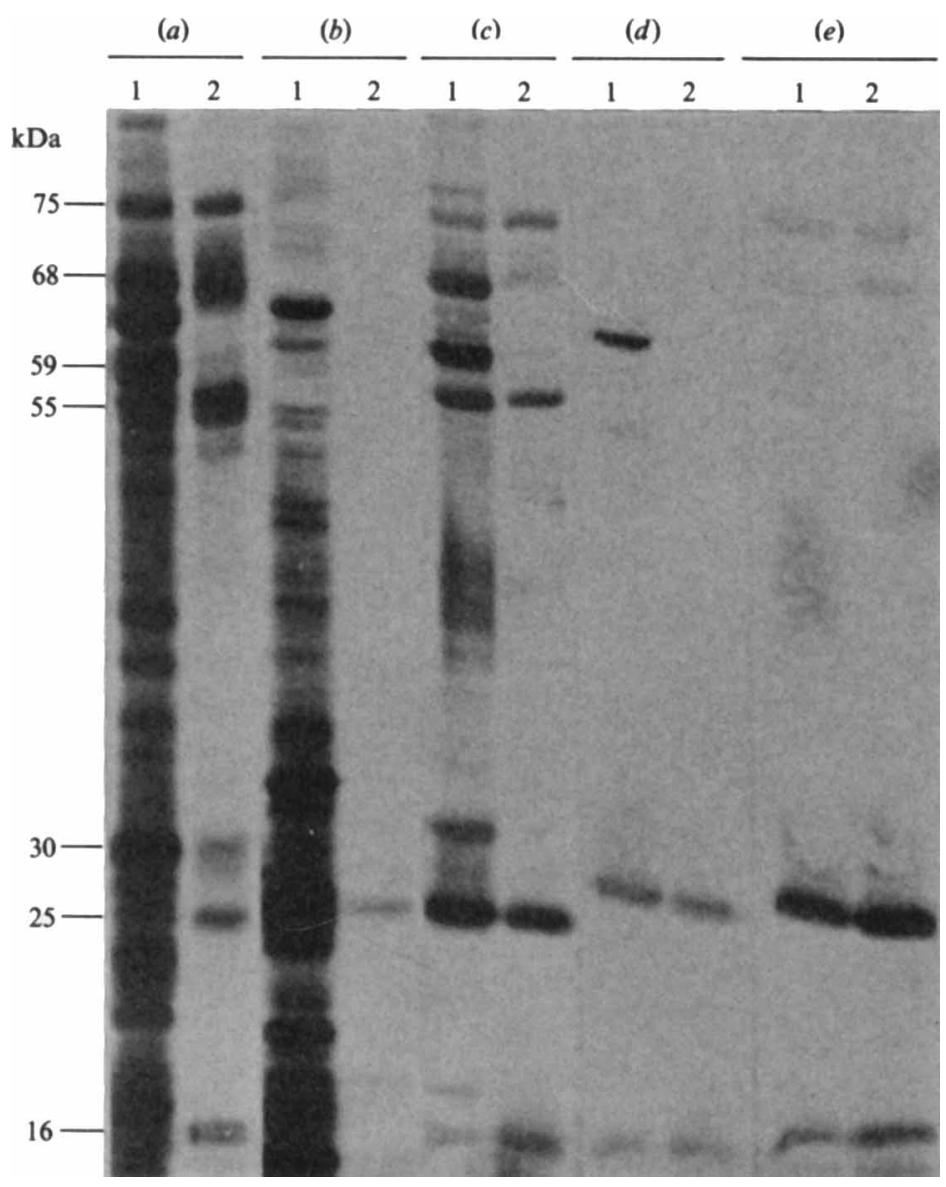

Fig. 4. Analysis of the haemagglutinin sample by SDS-PAGE and immunoblotting. $(a, b)$ SDS-PAGE gels stained with Coomassie brilliant blue and by the silver stain method, respectively. $(c, d, e)$ Western blotting with anti-whole-cell serum, HAA and HSA, respectively. Lanes: 1 , whole cells $(50 \mu \mathrm{g}$ protein per lane) of strain $136292 ; 2$, haemagglutinin sample prepared from strain 136292 [15 $\mu \mathrm{g}$ protein per lane except lane 2 of $(a)$ in which $45 \mu \mathrm{g}$ protein was applied].

whole cell and haemagglutinin samples reacted more strongly with the HSA than with the HAA (Fig. 4e). The HSA also reacted with the $16 \mathrm{kDa}$ polypeptide.

When the haemagglutinin sample $(15 \mu \mathrm{g}$ protein per lane) was run in an SDS-PAGE gel, no significant carbohydrate was detected by the sensitive silver stain method of Dubray \& Bezard (1982) (data not shown).

\section{Examination of $H$. pylori haemagglutinin by electron microscopy}

The negatively stained haemagglutinin sample revealed vesicle-like structures of various sizes (Fig. $5 a$ ). Thin sectioning of erythrocytes agglutinated by the haemagglutinin sample showed close apposition of the vesicle surface to the surface of erythrocytes and bridging between erythrocytes by the vesicles (Fig. $5 b, c$ ). The attachment of the vesicles to the erythrocytes was visually similar to that seen between $H$. pylori bacteria and the erythrocytes (Fig. $5 d, e$ ). However, despite numerous attempts the detailed morphological and structural nature of the haemagglutinin on the surface of the vesicles was not resolved.

\section{Discussion}

Fresh erythrocytes have previously been used for receptor-binding assays similar to that employed in this study (e.g., Haynes et al., 1988). However, a major problem arising when fresh erythrocytes were used herein was the haemolysis which occurred at the elution step where either an acidic buffer (usually $\mathrm{pH} 2.2$ or thereabouts) or a high salt concentration had to be used. To overcome this problem formaldehyde-fixed erythrocytes were utilized successfully instead of fresh ones. Formaldehyde-treated erythrocytes have long been used for passive HA assays, but the exact surface changes caused by the treatment with formaldehyde remain unclear. No matter what the changes might be, identical HA titres and patterns were shown by untreated erythrocytes and by erythrocytes treated with formaldehyde, indicating that the receptors involved in haemagglutination with $H$. pylori, at least for the strains used in this study, were not significantly affected by this chemical treatment.

Both the 25 and $59 \mathrm{kDa}$ polypeptide antigens of the haemagglutinating strain 136292 were found to absorb to 


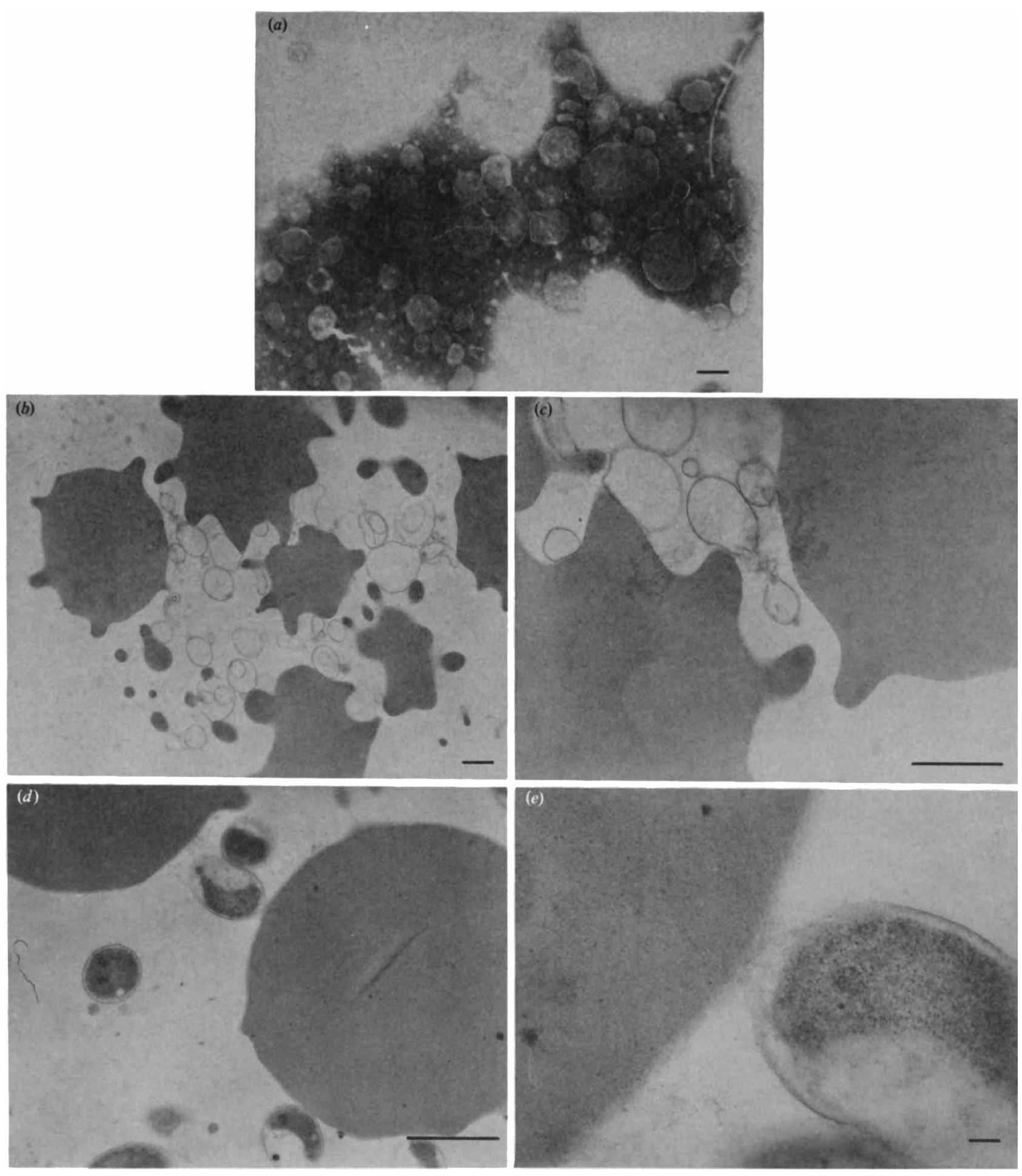

Fig. 5. Electron microscopy of the purified haemagglutinin of $H$.pylori strain 136292 and of the interactions of strain 136292 and its haemagglutinin with erythrocytes. (a) Negatively stained haemagglutinin sample of $H$. pylori strain 136292 . Sample stained with silicotungstate. Bar, $100 \mathrm{~nm}$. (b, c) Thin section view of interaction between haemagglutinin sample of $H . p y l o r i$ strain 136292 and dog erythrocytes. $(c)$ is a higher magnification view. Samples stained with uranyl acetate and lead citrate. Bars, $1 \mu \mathrm{m} .(d, e)$ Thin section view of interaction between agar-grown bacterial cells of $H$. pylori strain 136292 and dog erythrocytes. (e) is a higher magnification view. Bars, $1 \mu \mathrm{m}(d)$ and $100 \mathrm{~nm}(e)$. 
formaldehyde-treated erythrocytes as revealed by the direct binding, elution and immunoblotting assay. However, of these two bands only the $25 \mathrm{kDa}$ polypeptide antigen was present in the haemagglutinin sample which showed clear NeuAc-lactose (ex bovine colostrum) sensitive and neuraminidase-sensitive (by treatment of erythrocytes) HA activity. These findings strongly indicated that the $25 \mathrm{kDa}$ polypeptide antigen of strain 136292 was a NeuAc-lactose-specific erythrocyte-binding antigen. This antigen most probably recognizes the NeuAc $(\alpha 2-3)$ moiety of the receptor as suggested by several studies (Evans et al., 1988; Slomiany et al., 1989; Robinson et al., 1990; Saitoh et al., 1991).

The $59 \mathrm{kDa}$ polypeptide antigen proved to be another erythrocyte-binding antigen but of unknown receptor specificity. This was suggested both by the erythrocytebinding test and by the Western blotting analysis of whole-cell protein and the purified haemagglutinin using the HAA, which reacted with both the 59 and $25 \mathrm{kDa}$ antigens of the whole-cell sample but only with the $25 \mathrm{kDa}$ antigen of haemagglutinin sample. This HAA was prepared by absorption of anti-whole-cell serum against agar-grown bacteria of strain 136292 with nonhaemagglutinating broth-grown bacteria of the same strain. Thus, the HAA was supposed to recognize antigens that were associated with haemagglutination. It seems unlikely that the $25 \mathrm{kDa}$ and the $59 \mathrm{kDa}$ polypeptide antigens were associated as polypeptides of the same protein, not only because the $59 \mathrm{kDa}$ polypeptide antigen was completely removed from the haemagglutinin sample of strain 136292 , but also because the $59 \mathrm{kDa}$ polypeptide antigen did not bind as well as the $25 \mathrm{kDa}$ polypeptide antigen to goat erythrocytes in the case of strain 172460 (Fig. 3, lane 7). Failure to detect the $59 \mathrm{kDa}$ polypeptide in the partially purified haemagglutinin may have been due to complete solubilization by NOG extraction, since any truly soluble material would not be obtained by the protocol used (Fig. 1).

These findings might explain why neuraminidase treatment and NeuAc-lactose addition did not strongly inhibit haemagglutination with whole bacterial cells but did with the haemagglutinin sample. Robinson et al. (1990) suggested that different haemagglutinins might be present on $H$. pylori cells and, thus, that more than one type of receptor might be involved in the ligand-receptor interaction. Indeed, the different affinities of intact and sonicated $H$. pylori cells for the glycolipid receptors $\mathrm{GM}_{3}$ and galactosylceramide sulphate reinforces this view (Saitoh et al., 1991). The present study agrees with this concept and provides evidence for the presence of more than one adhesin at a molecular level. It seems reasonable to speculate that the $25 \mathrm{kDa}$ polypeptide recognises $\operatorname{NeuAc}(\alpha 2-3)$ of ganglioside $\mathrm{GM}_{3}$ and that the $59 \mathrm{kDa}$ polypeptide may be the ligand for galactosylceramide sulphate.

Strain 172460 only agglutinated goat erythrocytes. Its erythrocyte-binding antigen was found to cross-react with the $25 \mathrm{kDa}$ polypeptide antigen of strain 136292 , but had a slightly lower molecular mass than that of strain 136292 . However, the specificity of the receptor on goat erythrocytes for the $24 \mathrm{kDa}$ polypeptide antigen of strain 172460 is not known. Agglutination of goat erythrocytes by strain 172460 was not inhibited by NeuAc-lactose from human milk and bovine colostrum. Moreover, its $24 \mathrm{kDa}$ polypeptide antigen did not absorb to dog erythrocytes as did the $25 \mathrm{kDa}$ polypeptide antigen of strain 136292 (Fig. 3), suggesting that its receptor specificity is different. Interestingly, strain 184858 which did not agglutinate human, dog or goat erythrocytes also contained both 25 and $59 \mathrm{kDa}$ polypeptide antigens, but neither was found to bind to the erythrocytes tested. These results indicate that the antigenic cross-reactivities belie $\mathrm{HA}$ activities.

Another possibility is that the 25 and $59 \mathrm{kDa}$ polypeptide antigens may be two universal types of receptor-binding proteins for all or most of the strains of $H$. pylori. The 25 and $59 \mathrm{kDa}$ polypeptides, respectively, from different strains may be serologically related, closely or distantly. In receptor-binding specificity, they may be different, at least in vitro as suggested by this study. Uropathogenic Escherichia coli can express serologically identical fimbriae with different receptor-binding specificities (Lund et al., 1988). By analogy, it is possible that the $25 \mathrm{kDa}$ polypeptides of different $H$.pylori strains may differ in structure, reflected by different molecular masses and serological reactivity, and thus in the extent to which their epitope recognition sites can bind to $\operatorname{NeuAc}(\alpha 2-3)$, thereby imparting different properties in binding and $\mathrm{HA}$ assays.

In the studies of Fauchère and coworkers (Fauchère $e t$ al., 1989; Fauchère \& Blaser, 1990), some easily extractable adherent material [designated superficial adhering material (SAM)] of $\boldsymbol{H}$. pylori bound to HeLa cell membranes. This binding was not inhibited by addition of NeuAc or by pretreatment of HeLa cell membranes with $C$. perfringens neuraminidase, and a major antigen of approximately $60 \mathrm{kDa}$ was present in the chromatography fraction exhibiting the maximum adherence activity. From the property of the binding and the molecular mass of the antigen reported, this SAM antigen seems similar to the $59 \mathrm{kDa}$ antigen described in this study. However, Fauchère and coworkers seemed unsure whether the $60 \mathrm{kDa}$ antigen was the receptorbinding antigen or was copurified with urease, as the SAM-derived antigen was recognized by an anti-urease serum tested by them. 
The haemagglutinin was extracted from $H$. pylori in such a way as to retain the ability to agglutinate erythrocytes directly. Electron microscopy demonstrated vesicular material, the surfaces of which attached to the surfaces of erythrocytes. A similar attachment was seen between the bacteria and the erythrocytes. However, the morphological nature of the haemagglutinin itself was not revealed. Evans et al. (1988) reported that the $H$. pylori haemagglutinin was fibrillar but no molecular analysis was given, making comparisons with the present material difficult. However, on the basis of the electron micrographs presented by Evans et al. (1988), their fibrillar haemagglutinin may have been contaminated by LPS or the haemagglutinin may have been absorbed onto LPS vesicles which are morphologically similar by electron microscopy to the material described by these authors (Kuno et al., 1986).

The relationship, if any, between the $25 \mathrm{kDa}$ polypeptide antigen and other polypeptide bands, particularly the $16 \mathrm{kDa}$ polypeptide, seen in SDS-PAGE gels is not certain. Although both the 16 and $25 \mathrm{kDa}$ polypeptides reacted with both the HAA and the HSA, it is unclear whether the $16 \mathrm{kDa}$ polypeptide antigen in the purified haemagglutinin sample was a breakdown product of the $25 \mathrm{kDa}$ polypeptide. Monoclonal or polyclonal antibodies specific to the $25 \mathrm{kDa}$ polypeptide or the $16 \mathrm{kDa}$ polypeptide would be required to make this distinction. However, given that the purified haemagglutinin was prepared in the presence of protease inhibitors, it seems unlikely that the $16 \mathrm{kDa}$ polypeptide is related to the $25 \mathrm{kDa}$ polypeptide as a breakdown product. The role, if any, of the haemagglutinin antigens described herein in adherence of $H$. pylori to antral or duodenal epithelium remains to be established.

This research was supported by a grant from the Health Research Board of Ireland. J.H. held a HRB studentship. The authors thank David John and Colin Reid of the Electron Microscope Unit, Trinity College, Dublin, Republic of Ireland for performing those parts of the studies reported here.

\section{References}

BURNETTE, W. N. (1982). 'Western blotting': electrophoretic transfer of proteins from sodium dodecyl sulfate-polyacrylamide gels to unmodified nitrocellulose and radiographic detection with antibody and radioiodinated Protein A. Analytical Biochemistry 112, 195-203.

DUBRAY, G. \& Bezard, G. (1982). A highly sensitive periodic acidsilver stain for 1,2-diol group of glycoproteins and polysaccharides in polyacrylamide gels. Analytical Biochemistry 119, 325-329.

Dunn, B. E., Altmann, M. \& Campbell, G. P. (1991). Adherence of Helicobacter pylori to gastric carcinoma cells: analysis by flow cytometry. Reviews of Infectious Diseases 13, Supplement 8, S657S664.

Emödy, L., Carlsson, A., LuUngh, ^. \& Wadström, T. (1988). Mannose-resistant hemagglutination by Campylobacter pylori. Scandinavian Journal of Infectious Diseases 20, 353-354.

Evans, D. G., Evans, D. J., JR, Moulds, J. J. \& Graham, D. Y. (1988). $\mathrm{N}$-acetylneuraminyllactose-binding fibrillar haemagglutinin of $\mathrm{Cam}$ pylobacter pylori: a putative colonization factor antigen. Infection and Immunity 56, 2896-2906.

Evans, D. G., Evans, D. J., JR \& GrahaM, D. Y. (1989). Receptormediated adherence of Campylobacter pylori to mouse Y-1 adrenal cell monolayers. Infection and Immunity 57, 2272-2278.

FAUChÈRE, J. L. \& BlASER, M. J. (1990). Association of Helicobacter pylori with epithelial cells. In Helicobacter pylori, Gastritis and Peptic Ulcer, pp. 110-117. Edited by P. Malfertheiner \& H. Ditschuneit. Berlin: Springer-Verlag.

FAUChère, J. L., ZhiHENG, P. \& BlaSer, M. J. (1989). Adherence of superficial components of Campylobacter pylori to epithelial cell membranes. Klinische Wochenschrift 67, Supplement 18, 19.

Haynes, J. D., Dalton, J. P., Klotz, F. W., McGinniss, M. H., Hadley, T. J., Hudson, D. E. \& Miller, L. H. (1988). Receptor-like specificity of a Plasmodium knowlesi malarial protein that binds to Duffy antigen ligands on erythrocytes. Journal of Experimental Medicine 167, 1873-1881.

Huang, J., Smyth, C. J., Kennedy, N. P., Arbuthnott, J. P. \& KeELING, P. W. N. (1988). Haemagglutinating activity of Campylobacter pylori. FEMS Microbiology Letters 56, 109-112.

Kuno, T., Naito, S., Ohta, M., Kido, N., Ito, H. \& Kato, N. (1986). Staining of $\mathrm{O}$-specific polysaccharide chains of lipopolysaccharides with ruthenium red. Microbiology and Immunology 30, 734-751.

LAEMMLI, U. K. (1970). Cleavage of structural proteins during the assembly of the head of bacteriophage T4. Nature, London 227, 680685.

Lingwood, C. A., Law, H., Pellizzari, A., Sherman, P. \& Drumm, B. (1989). Gastric glycerolipid as a receptor for Campylobacter pylori. Lancet ii, 238-241.

Lund, B., Marklund, B.-I., STrömberg, N., Lindberg, F., KarLSSON, K.-A. \& NormarK, S. (1988). Uropathogenic Escherichia coli can express serologically identical pili of different receptor binding specificities. Molecular Microbiology 2, 255-263.

Markwell, M. A. K., HaAs, S. M., Bieber, L. L. \& Tolbert, N. E. (1978). A modification of the Lowry procedure to simplify protein determination in membrane and lipoprotein samples. Analytical Biochemistry 87, 206-210.

Nakazawa, T., Ishibashi, M., Konishi, H., Takemoto, T., Shigeeda, M. \& KoCHIYAMA, T. (1989). Hemagglutination activity of Campylobacter pylori. Infecion and Immunity 57, 989-991.

Neman-Simha, V. \& Megrand, F. (1988). In vitro model for Campylobacter pylori adherence properties. Infection and Immunity 56, 3329-3333.

Neman-Simha, V. Brugtmann, D. \& Megrand, F. (1989). Interaction of Campylobacter pylori with epithelial cells: role of the urease. Klinische Wochenschrift 67, Supplement 18, 48.

Robinson, J., Goodwin, C. S., CoOper, M., Burke, V. \& Mee, B. J. (1990). Soluble and cell-associated haemagglutinins of Helicobacter (Campylobacter) pylori. Journal of Medical Microbiology 33, 277-284.

Saitoh, T., Natomi, H., Zhao, W., Okuzumi, K., Sugano, K., IWAMORI, M. \& NAGAI, Y. (1991). Identification of glycolipid receptor for Helicobacter pylori by TLC-immunostaining. FEBS Letters 282, 385-387.

Slomiany, B. L., Piotrowski, J., Samanta, A., VanHorn, K., MURTY, V. L. N. \& SlomianY, A. (1989). Campylobacter pylori colonization factor shows specificity for lactosylceramide sulfate and GM3 ganglioside. Biochemistry International 19, 929-936.

Wray, W., Boulikas, T., Wray, V. P. \& Hancock, R. (1981). Silver staining of proteins in polyacrylamide gels. Analytical Biochemistry 118, 197-203. 